6. Chamberlain MC, Johnston SK: High-dose methotrexate and rituximab with deferred radiotherapy for newly diagnosed primary B-cell CNS lymphoma. Neuro-Oncology 12:736-744, 2010

7. Batchelor TT, Grossman SA, Mikkelsen T, et al: Rituximab monotherapy for patients with recurrent primary CNS Iymphoma. Neurology 76:929-930, 2011
8. Reni $M$, Zaja $F$, Mason $W$, et al: Temozolomide as salvage treatment in primary brain lymphomas. Br J Cancer 96:864-867, 2007

DOI: 10.1200/JCO.2013.53.7084; published online ahead of print at www.jco.org on February 3, 2014

\section{Reply to M.C. Chamberlain}

Cancer and Leukemia Group B (CALGB) 50202 was the first clinical trial to demonstrate the feasibility of dose-intensive consolidative chemotherapy in the multicenter setting for newly diagnosed patients with primary CNS lymphoma (PCNSL). The CALGB 50202 regimen consists of a novel induction regimen, consisting of twiceweekly high-dose methotrexate $e^{1,2}$ in combination with weekly rituximab, ${ }^{3-6}$ plus monthly temozolomide (MT-R). ${ }^{7-9}$ Rituximab is administered for six doses, during the first 6 weeks of induction, an interval during which the blood-brain barrier may be most significantly disrupted by angiotropic lymphoma. ${ }^{10,11}$ Patients who achieved a complete response to MT-R received high-dose, infusional etoposide in combination with twice-daily, high-dose cytarabine, over 4 days $^{12-16}$ (Table 1). Two thirds of the patients achieved a complete response with MT-R induction, the median progression-free survival (PFS) at 2 years was 59\%, the median PFS was 4 years and the 4 -year overall survival probability was $65 \%$. As noted in the editorial ${ }^{17}$ that accompanies the article, the results of 50202 are comparable or superior to results obtained in other prospective multicenter trials that included whole-brain radiotherapy. Notably, the striking PFS of those who completed consolidation dose-intensive chemotherapy replicates the institutional experience with this regimen in PCNSL, dating to 2001. ${ }^{13}$ Moreover, for the first time in a clinical trial in PCNSL, patients age 60 years or older had outcomes similar to younger patients, highlighting another significant advantage of the dose-intensive consolidation approach used in 50202 compared with consolidative whole-brain radiotherapy. The recent finding that patients with PCNSL age 60 years or older have inferior outcomes with even reduced-dose whole-brain radiotherapy would seem to further underscore the advantage of dose-intensive chemotherapeutic consolidation. ${ }^{18}$ Regarding the question of whether CALGB 50202 is

\begin{tabular}{|c|c|}
\hline Therapy Regimen & Reference \\
\hline \multicolumn{2}{|l|}{ Remission Induction Therapy: MT-R (14-day cycle) } \\
\hline Day $1 \mathrm{MTX} 8$ grams $/ \mathrm{m}^{2}$ IV over 4 hrs & $1-2$ \\
\hline \multicolumn{2}{|l|}{$\begin{array}{l}\text { Day } 2 \text { leukovorin } 100 \mathrm{mg} / \mathrm{m}^{2} \text { every } 6 \text { hrs, until MTX } \\
\text { clearance }\end{array}$} \\
\hline Day 3 rituximab 375 mg/m² IV weeks 1 through 6 & $3-6,10$ \\
\hline Day 7-11 temozolomide 150 mg/m² PO odd cycles only & $7-8$ \\
\hline \multicolumn{2}{|l|}{ Consolidation Therapy: EA } \\
\hline \multicolumn{2}{|l|}{ Day 1-4 etoposide $40 \mathrm{mg} / \mathrm{kg}$ continuous infusion } \\
\hline \multicolumn{2}{|l|}{ Days $1-4$ cytarabine $2 \mathrm{gm} / \mathrm{m}^{2}$ IV over 2 hrs every } \\
\hline 12 hrs $\times 8$ doses & $14,26-30$ \\
\hline \multicolumn{2}{|c|}{$\begin{array}{l}\text { Abbreviations: CALGB, Cancer and Leukemia Group B; EA, etoposide and } \\
\text { cytarabine; IV, intravenous; MT-R, methotrexate, rituximab and temozolo- } \\
\text { mide; MTX, methotrexate; PO, orally. }\end{array}$} \\
\hline
\end{tabular}

practice-changing, considering the outcomes obtained with the 50202 regimen in the multicenter setting, and the preponderance of evidence that brain radiotherapy, even at reduced doses, is neurotoxic ${ }^{19-21}$ and associated with a long-term increased risk of de novo secondary brain neoplasms, ${ }^{22,23}$ we ask the question, what hematologist/oncologist, neurologist, or patient with PCNSL would recommend or prefer to receive whole-brain radiotherapy, at any dose, as consolidation in first remission, if dose-intensive chemotherapeutic consolidation is available as an option?

To address the comments of Chamberlain ${ }^{24}$ regarding the rationale for the number of cycles of methotrexate used, and the role of rituximab, temozolomide and etoposide, we suggest a review of the explanations and references provided in the text of the manuscript and in Table 1 of this letter, as well as an assessment of the outcomes of patients treated in CALGB 50202 (Fig 2 of the publication), with a 2 -year PFS that is without precedent in a multicenter study involving chemotherapy without brain radiotherapy in PCNSL. ${ }^{25,26}$ In regards to the number of doses of cytarabine at consolidation, Chamberlain should note that similar schedules of high-dose cytarabine actually are in fact used to treat other hematologic malignancies that are associated with poor prognosis, such as mantle-cell lymphoma and acute myelogenous leukemia. ${ }^{27-31}$ We certainly agree with Chamberlain, however, that there is a significant need to improve the 50202 regimen and advocate that the best means to contribute to this effort and to enhance outcomes for PCNSL patients is via active participation in prospective clinical trials such as CALGB 51101, the successor and an intergroup study and first randomized trial for PCNSL that does not involve brain radiotherapy. Notably, given the correlative end points embedded within the trial, participation in this important study by the hematology/oncology and neuro-oncology community will also significantly enhance our understanding of the patient with PCNSL's quality of life and disease biology, creating a foundation for trials that address molecular targets and prognostic risk groups and lead to further improvements in outcomes in this previously highly refractory form of non-Hodgkin lymphoma. ${ }^{32}$

\section{James L. Rubenstein}

Helen Diller Comprehensive Cancer Center, University of California, San Francisco, CA

\section{Bruce D. Cheson}

Georgetown University Hospital, Washington, DC

\section{Sin-Ho Jung}

Alliance Statistics and Data Center, Duke Comprehensive Cancer Center, Duke University, Durham, NC

\section{Lawrence D. Kaplan}

Helen Diller Comprehensive Cancer Center, University of California, San Francisco, CA

\section{ACKNOWLEDGMENT}

Supported by Grants No. RO1CA1398301 (J.L.R.), CA60138 (J.L.R.), CA77597 (B.D.C.), and CA33601 (S.-H.J.). 
AUTHORS' DISCLOSURES OF POTENTIAL CONFLICTS OF INTEREST Employment or Leadership Position: None Consultant or Advisory Role: None Stock Ownership: None Honoraria: James L. Rubenstein, Up To Date; Lawrence D. Kaplan, Up To Date Research Funding: James L. Rubenstein, Genentech, Celgene Expert Testimony: None Patents, Royalties, and Licenses: None Other Remuneration: None

\section{REFERENCES}

1. Glantz MJ, Cole BF, Recht $L$, et al: High-dose intravenous methotrexate for patients with nonleukemic leptomeningeal cancer: Is intrathecal chemotherapy necessary? J Clin Oncol 16:1561-1567, 1998

2. Batchelor T, Carson K, O'Neill A, et al: Treatment of primary CNS lymphoma with methotrexate and deferred radiotherapy: A report of NABTT 96-07. J Clin Oncol 21:1044-1049, 2003

3. Rubenstein JL, Combs D, Rosenberg J, et al: Rituximab therapy for CNS lymphomas: Targeting the leptomeningeal compartment. Blood 101:466-468, 2003

4. Rubenstein JL, Fridlyand J, Abrey L, et al: Phase I study of intraventricular administration of rituximab in patients with recurrent CNS and intraocular lymphoma. J Clin Oncol 25:1350-1356, 2007

5. Batchelor TT, Grossman SA, Mikkelsen T, et al: Rituximab monotherapy for patients with recurrent primary CNS lymphoma. Neurology 76:929-930, 2011

6. Kadoch C, Li J, Wong VS, et al: Complement activation and intraventricular rituximab distribution in recurrent central nervous system lymphoma. Clin Cancer Res [epub ahead of print on November 7, 2013]

7. Reni M, Mason W, Zaja F, et al: Salvage chemotherapy with temozolomide in primary CNS lymphomas: Preliminary results of a phase II trial. Eur J Cancer 40:1682-1688, 2004

8. Reni M, Zaja F, Mason $W$, et al: Temozolomide as salvage treatment in primary brain lymphomas. Br J Cancer 96:864-867, 2007

9. Osoba D, Brada M, Yung WK, et al: Health-related quality of life in patients treated with temozolomide versus procarbazine for recurrent glioblastoma multiforme. J Clin Oncol 18:1481-1491, 2000

10. Ott RJ, Brada M, Flower MA, et al: Measurements of blood-brain barrier permeability in patients undergoing radiotherapy and chemotherapy for primary cerebral lymphoma. Eur J Cancer 27:1356-1361, 1991

11. Rubenstein JL, Fridlyand J, Shen $A$, et al: Gene expression and angiotropism in primary CNS lymphoma. Blood 107:3716-3723, 2006

12. Soussain C, Suzan F, Hoang-Xuan $K$, et al: Results of intensive chemotherapy followed by hematopoietic stem-cell rescue in 22 patients with refractory or recurrent primary CNS Iymphoma or intraocular lymphoma. J Clin Oncol 19:742749, 2001

13. Wieduwilt MJ, Valles F, Issa $S$, et al: Immunochemotherapy with intensive consolidation for primary CNS Iymphoma: A pilot study and prognostic assessment by diffusion-weighted MRI. Clin Cancer Res 18:1146-1155, 2012

14. Ferreri AJ, Reni M, Foppoli M, et al: High-dose cytarabine plus high-dose methotrexate versus high-dose methotrexate alone in patients with primary CNS lymphoma: A randomised phase 2 trial. Lancet 374:1512-1520, 2009

15. Relling MV, Mahmoud $\mathrm{HH}$, Pui $\mathrm{CH}$, et al: Etoposide achieves potentially cytotoxic concentrations in CSF of children with acute lymphoblastic leukemia. J Clin Oncol 14:399-404, 1996
16. Boehme V, Zeynalova $S$, Kloess $M$, et al: Incidence and risk factors of central nervous system recurrence in aggressive lymphoma: A survey of 1693 patients treated in protocols of the German High-Grade Non-Hodgkin's Lymphoma Study Group (DSHNHL). Ann Oncol 18:149-157, 2007

17. Batchelor TT: Flying solo: Chemotherapy without radiation for primary CNS Iymphoma. J Clin Oncol 31:3051-3053, 2013

18. Morris PG, Correa DD, Yahalom J, et al: Rituximab, methotrexate, procarbazine, and vincristine followed by consolidation reduced-dose whole-brain radiotherapy and cytarabine in newly diagnosed primary CNS Iymphoma: Final results and long-term outcome. J Clin Oncol 31:3971-3979, 2013

19. Sun A, Bae K, Gore EM, et al: Phase III trial of prophylactic cranial irradiation compared with observation in patients with locally advanced non-small-cell lung cancer: Neurocognitive and quality-of-life analysis. J Clin Oncol 29:279-286, 2011

20. Mizumatsu S, Monje ML, Morhardt DR, et al: Extreme sensitivity of adult neurogenesis to low doses of X-irradiation. Cancer Res 63:4021-4027, 2003

21. Monje ML, Mizumatsu S, Fike JR, et al: Irradiation induces neural precursor-cell dysfunction. Nat Med 8:955-962, 2002

22. Relling MV, Rubnitz JE, Rivera GK, et al: High incidence of secondary brain tumours after radiotherapy and antimetabolites. Lancet 354:34-39, 1999

23. Walter AW, Hancock ML, Pui $\mathrm{CH}$, et al: Secondary brain tumors in children treated for acute lymphoblastic leukemia at St Jude Children's Research Hospital. J Clin Oncol 16:3761-3767, 1998

24. Chamberlain MC: Should dose-intense immnochemotherapy be the new standard of care for primary CNS Iymphoma? J Clin Oncol 32:857-858, 2014

25. Rubenstein JL, Hsi ED, Johnson JL, et al: Intensive chemotherapy and immunotherapy in patients with newly diagnosed primary CNS lymphoma: CALGB 50202 (Alliance 50202). J Clin Oncol 31:3061-3068, 2013

26. Rubenstein JL, Gupta NK, Mannis GN, et al: How I treat CNS lymphomas. Blood 122:2318-2330, 2013

27. Damon L, Damon LE, Gaensler K, et al: Impact of intensive PBSC mobilization therapy on outcomes following auto-SCT for non-Hodgkin's lymphoma. Bone Marrow Transplant 42:649-657, 2008

28. Damon LE, Johnson JL, Niedzwiecki D, et al: Immunochemotherapy and autologous stem-cell transplantation for untreated patients with mantle-cell Iymphoma: CALGB 59909. J Clin Oncol 27:6101-6108, 2009

29. Schaich M, Parmentier S, Kramer M, et al: High-dose cytarabine consolidation with or without additional amsacrine and mitoxantrone in acute myeloid leukemia: Results of the prospective randomized AML2003 trial. J Clin Oncol 31:2094-2102, 2013

30. Schaich M, Röllig C, Soucek $S$, et al: Cytarabine dose of $36 \mathrm{~g} / \mathrm{m}^{2}$ compared with $12 \mathrm{~g} / \mathrm{m}^{2}$ within first consolidation in acute myeloid leukemia: Results of patients enrolled onto the prospective randomized AML96 study. J Clin Oncol 29:2696-2702, 2011

31. Linker CA, Owzar $K$, Powell $B$, et al: Auto-SCT for AML in second remission: CALGB study 9620. Bone Marrow Transplant 44:353-359, 2009

32. Ponzoni M, Issa S, Batchelor TT, et al: Beyond high-dose methotrexate and brain radiotherapy: Novel targets and agents for primary CNS lymphoma. Ann Oncol [epub ahead of print on November 30, 2013]

DOI: $10.1200 / J C 0.2013 .53 .8942$; published online ahead of print at www.jco.org on February 3, 2014

\section{Do We Really Need Another Epidermal Growth Factor Receptor Tyrosine Kinase Inhibitor in First-Line Treatment for Patients With Non-Small-Cell Lung Cancer and EGFR Mutations?}

To THE EDitor: Sequist et $\mathrm{al}^{1}$ recently published in Journal of Clinical Oncology the results of a phase III study comparing afatinib to standard first-line chemotherapy in patients with metastatic lung adenocarcinoma with EGFR mutations.
Since 2004, when EGFR became a target, ${ }^{2-4}$ three similar molecules have been studied and developed for the same indication. So far, three drugs (gefitinib, erlotinib, and afatinib) have been approved as first-line treatment in a population representing approximately $10 \%$ of patients with non-small-cell lung cancer (NSCLC). Furthermore, to our knowledge, at least one other drug ${ }^{5}$ is under investigation for the same population.

The regulatory agencies accepted the commercialization of a third drug without any direct comparison with the other two already-marketed drugs in such a small subset of patients. Nevertheless, we need to understand how afatinib could possibly be implemented in clinical practice. At the date the LUX-Lung 3 trial was started, data on IPASS were already known, and gefitinib was already considered standard first-line treatment for EGFR-mutated patients, as was erlotinib later on. 